\title{
THE IMPLEMENTATION OF THE STRENGTHENING CHARACTER EDUCATION IN SDN 09 MATARAM CITY, NTB
}

\author{
Nur Listiawati \\ Center for Policy Research on Education and Culture, MOEC Indonesia \\ Email: n.listiawati07@gmail.com
}

\begin{abstract}
This research is a qualitative one that attempts to illustrate the implementation of the 5 main values of Strengthening Character Education (religious, nationalist, self-reliance, mutual cooperation and integrity) and other Core values that are prioritized in the target school. This is a case study in one of the primary schools in Mataram City, Nusa Tenggara Barat, Indonesia. The study used an inductive reasoning approach. This approach aims to generate meaning from data collected which is based on learning and experience. Data were obtained through an interview, observation, a study of documents, and focused group discussion. The results show that planting and implementing the values has been done through various themes or activities programs. Some obstacles emerged in the implementation activities and had been solve by rearranging schedule, communication, coordination between school's elements and parents, adjustment between the concept of Curriculum 2013 and Strengthening Character Education, therefore besides 4C (Critical Thinking, Communication skill, Creativity and Innovation, and Collaboration), it is better to consider to increase 3C (Communication, Coordination and Cooperation) in character education. In implementing this character education, there are supporting factors such as principal's leadership, other elements of the school, and school network.
\end{abstract}

Keywords: character education, character value, implementation, students, primary school

\section{IMPLEMENTASI PENGUATAN PENDIDIKAN KARAKTER DI SDN 9 KOTA MATARAM NUSA TENGGARA BARAT}

\begin{abstract}
Abstrak: Kajian ini merupakan kajian kualitatif yang berupaya menggambarkan penerapan lima nilai utama Penguatan Pendidikan Karakter (agama, nasionalis, kemandirian, gotong-royong dan integritas) serta nilai inti yang diprioritaskan di sekolah sasaran penelitian. Ini merupakan studi kasus di salah satu sekolah dasar di Kota Mataram, Nusa Tenggara Barat. Kajian ini menggunakan pendekatan inductive reasoning. Pendekatan ini bertujuan untuk menghasilkan makna dari data yang dikumpulkan yang didasarkan pada pembelajaran dan pengalaman. Data diperoleh melalui wawancara, observasi, studi dokumen, dan diskusi kelompok terfokus. Hasilnya menunjukkan bahwa penanaman dan penerapan nilai-nilai karakter sudah dilakukan melalui berbagai tema atau kegiatan. Beberapa hambatan muncul dalam penerapannya dan dapat diatasi dengan cara perbaikan jadwal, komunikasi, koordinasi antarpihak di sekolah dan orang tua, serta penyesuaian konsep Kurikulum 2013 dan Penguatan Pendidikan Karakter sehingga selain 4C (Critical Thinking, Communication skill, Creativity dan Innovation, serta Collaboration) perlu dipertimbangkan peningkatan 3C (Communication, Coordination, dan Cooperation) dalam pendidikan karakter. Implementasi Penguatan Pendidikan Karakter didukung oleh kepemimpinan kepala sekolah, warga sekolah, dan kerja sama sekolah dengan masyarakat dan lembaga lainnya.
\end{abstract}

Kata Kunci: pendidikan karakter, nilai karakter, penerapan, siswa, sekolah dasar

\section{INTRODUCTION}

Character education cannot be separated from education in Indonesia since the beginning. Habituation, learning materials, learning and playing among students have included character values. However, there are still cases involving delinquency of children and adolescents in Indonesia. Data from Indonesian Child Protection Commission (KPAI) shows that children as perpetrators of violence have increased from 67 cases in 2014 to 87 cases in 2015. Similarly, 
children as fighters increased from 46 cases in 2014 to 103 cases in 2015 (Maskur, 2016). In education realm from 2011 to 2016, there were 1948 cases including students fight and bullying (KPAI, 2016). This condition becomes one of the driving force for the government to implement Strengthening Character Education.

Strengthening Character Education (Penguatan Pendidikan Karakter hereinafter referred to PPK) is a continuation of National Movement of Nation Character Education which has been proclaimed since 2010 . This program gives 'Strengthening' on Character education that has been done in school. In the National Movement of Nation Character Education, there are 18 character values, while in PPK the eighteenth values are summarized into 5 main character values as described below.

Table 1. Key Values, Embodiment through Attitudes and Behavior, and Other Values Covered

\begin{tabular}{|c|c|c|c|}
\hline No. & Key Values & $\begin{array}{c}\text { Embodiment through Attitudes and } \\
\text { Behaviors }\end{array}$ & $\begin{array}{l}\text { Other Values which are Covered in } \\
\text { Key Values }\end{array}$ \\
\hline & $\begin{array}{l}\text { Religious (the three di- } \\
\text { mensions of relation- } \\
\text { ship: the individual } \\
\text { relationship with God, } \\
\text { individual relation- } \\
\text { ship with other peo- } \\
\text { ple, individual with } \\
\text { environment/ uni- } \\
\text { verse) }\end{array}$ & $\begin{array}{l}\text { - carrying out the teachings of one religion } \\
\text { / other beliefs, } \\
\text { - uphold the tolerant attitude towards the } \\
\text { implementation of religious worship of } \\
\text { others } \\
\text { - respect for religious differences } \\
\text { - live in harmony and peace with } \\
\text { adherents of other religions } \\
\text { - love and keep the integrity of God } \\
\text { creation }\end{array}$ & $\begin{array}{l}\text { Love peace, tolerance, respect the } \\
\text { differences of religion and belief, firm } \\
\text { stance, confidence, cooperation } \\
\text { between adherents of different } \\
\text { religion and belief, anti-bullying and } \\
\text { violence, friendship, sincerity, not } \\
\text { impose the will, love the environment }\end{array}$ \\
\hline & Nationalist & $\begin{array}{l}\text { - Loyal, caring, high appreciation for } \\
\text { Indonesian language, physical } \\
\text { environment, social, and culture. } \\
\text { - Placing the interests of the nation and } \\
\text { state above the interests of oneself or a } \\
\text { group }\end{array}$ & $\begin{array}{l}\text { Appreciation of Indonesian culture, } \\
\text { safeguarding the nation's cultural } \\
\text { richness, willing to sacrifice, have } \\
\text { achievements, love the homeland, } \\
\text { protect the environment, obey the } \\
\text { law, discipline, respect the diversity } \\
\text { of culture, ethnicity, and religion. }\end{array}$ \\
\hline & Self-reliance & $\begin{array}{l}\text { - Not depend on others } \\
\text { - Use all the energy, mind, and time to } \\
\text { actualize the hopes, dreams, and ideas }\end{array}$ & $\begin{array}{l}\text { Hard work, resilient, adversity } \\
\text { quotient, professional, creative, } \\
\text { courage, and become lifelong } \\
\text { learners. }\end{array}$ \\
\hline & $\begin{array}{l}\text { Gotong-Royong } \\
\text { (mutual cooperation) }\end{array}$ & $\begin{array}{l}\text { - Appreciate the spirit of cooperation, } \\
\text { solve the problems together } \\
\text { - Establish communication and friendship } \\
\text { - Provide assistance for people in need. }\end{array}$ & $\begin{array}{l}\text { Appreciation, cooperation, } \\
\text { inclusiveness, commitment to mutual } \\
\text { decision, consensus deliberations, } \\
\text { help each other, solidarity, empathy, } \\
\text { anti-discrimination, nonviolence, and } \\
\text { volunteerism. }\end{array}$ \\
\hline & Integrity & $\begin{array}{l}\text { - the effort to become a person who is } \\
\text { always trustworthy in words, actions, } \\
\text { and work, has a commitment and loyalty } \\
\text { to humanitarian and moral values (moral } \\
\text { integrity). } \\
\text { - responsibility as a citizen, actively } \\
\text { involved in social life through the } \\
\text { consistency of actions and words based } \\
\text { on the truth }\end{array}$ & $\begin{array}{l}\text { - honesty, love for truth, faithfulness, } \\
\text { moral commitment, anti- } \\
\text { corruption, justice, responsibility, } \\
\text { exemplary, and respect for the } \\
\text { dignity of individuals (especially } \\
\text { persons with disabilities) }\end{array}$ \\
\hline
\end{tabular}

Source: Book of Concepts and Guidelines for Strengthening Character Education at the Elementary and Junior High School Level (Kementerian Pendidikan dan Kebudayaan, 2016) 
These five core values or other values cannot stand alone in the application. There is a link between one value and another. Character education is implemented according to curriculum structure that is Classbased, School-based, Culture and Community-based. Class-based is to instill values through a blend of intra-curricular learning, classroom management, utilization of teaching methods, thematic learning, literacy activities and counseling guidance. In this case, the teacher is expected to be able to develop student ability which includes critical thinking, communication skill, creativity and innovation, and collaboration (4C). While the school cultured based is the strengthening of character education based on habituation as the application of the character values prioritized in vision, mission, and school branding. Community-Based PPK deals with the school as an institution that needs support and cooperation with community members and other institutions around the school environment or more broadly the community or other institutions that are far away from the school.

Education is an effort done to optimize ethical behavior in students. In general, the main principles of good character are respect, truth, justice, and responsibility. It is believed that what happens with future students is related to the level of character that isembedded within themselves through education (Agboola and Tsai, 2012: 163). The above sentence implies that the school has important roles in the development of a child's character. Character education traces along the course of his life.

Battistich in his paper said:

Character is the realization of one's positive development as a person-intellectually, socially, emotionally, and ethically. To be a person of good character is to be the best person that one can be (Battistich, 2011:2).
The Character is considered as the realization of positive personality development of a person, either intellectually, socially, emotionally, or ethically. Good character is the most coveted goal. Character education contains 3 main elements that are knowing the good, doing the good and loving the good. Character education not only teaches children to be able to distinguish right and wrong, more than that character education teaches good practice to make good children (Ryan and Bohlin in Marzuki, 2011:27). A good character is the same as morality or "Budi Pekerti" in Indonesia. The importance of good character is conveyed in hadith of H.R. Bukhori that the Prophet Muhammad was sent to the earth with the mission to perfect morals or character (Sylviyanah, 2012:192). Thus the improvement of morality or character is very important according to Allah, the Creator.

The Governor of West Nusa Tenggara, Muhammad Zainul Majdi, is one of the leaders who welcomed the PPK program and said the NTB region would implement the PPK program gradually according to the readiness of the region (Khafid, 2016). The governor's statement increased the spirit and determination of the school to implement PPK programs. This study aims to provide an overview of the implementation of Strengthening Character Education in the SDN 09 in the city of Mataram, West Nusa Tenggara.

\section{METHOD}

This research aims to answer the research question on how the implementation of Strengthening Character Education in school in the city of Mataram, West Nusa Tenggara. This is a case study on one elementary school in Mataram City. Research is a qualitative one and seeks to illustrate the 
application of character values in the school's, seen from the application of the main or core values which in turn will relate to the application of other values as the subvalues. The study used an inductive approach or inductive reasoning. This approach aims to generate meaning from data collected which is based on learning and experience which are difficult to extract through conventional research methods (Strauss \& Corbin, 1998 in Dodge, 2011: 41). In qualitative research, the meaning resulted from the interpretation from the researcher's point of view and the values of the researcher included in it. This is in contrast to the quantitative research that is valuefree. Triangulation that has four types (Wilson, 2014), one of its uses to gather data in more than one method. Data were obtained through an interview with an the school principal, observation, a study of documents, and focused group discussion with principals, teachers, committees, and school supervisors.

\section{RESULTS AND DISCUSSION}

SDN 09 is one of the schools that received PPK training for principals, teachers, and school committees. In order for the materials and messages in the training to be known and understood by teachers in schools and other school residents, the school organizes socialization activities on basic concepts of PPK through quality assurance team meetings which formulates a joint policy on programs and strategic steps that will conducted in relation to the implementation of PPK including multiplying the slogans to motivate students and other school elements to implement character values. In addition to socialization activities at the school itself, there is a socialization conducted for teachers and other elementary school principals who are in one cluster which is conducted once a month in a meeting of teacher working group and Principal working group (KKG and K3S). In order for this program to be known by the community, the school conducted socialization through online media and school magazines.

According to Narvaez and Lapsley (2016:6), a strategy that teachers can use is to make the hidden character education curriculum explicit and encourage teachers to look at the educational outcomes of existing characters that emerge in good practices. While the maximal strategy is the teacher must learn pedagogical skills that target character education as an explicit curricular purpose, the educational process must be articulated and taught systematically. Thus the application of character values can be measured. Teaches children to have problem-solving skills as well as overcomes adversity encountered in everyday life is not less important. So the teaching of various knowledge must be based on character values. This is supported by the research results of Jolls (2008:48) that stated understanding of values is accompanied by the skills of analyzing, expressing something, and representing himself to make decisions to live his life. This is consistent with the scientific approach in the Curriculum 2013 that includes the ability to observe, ask, experiment, associate, process and analyze information, and draw conclusions and communicate the results of learning (Efrini, 2016:94). Therefore, planting the value of adversity Quotient which is a sub-value of self-reliance in Strengthening Character Education is very necessary. In addition to problem-solving skills in the theory of Adversity Quotient by Paul G. Stoltz, the application of the adversity quotient skills will ultimately lead a person to be tough and self-reliance. 
The vision of the school is to create it as a 'Diamond Park' with learners who are superior in their performance of science and technology, faith and piety, and behave culturally. The 'Diamond Park' is a Religious, Relaxing and Comfortable Learning place which used as the school branding. According to the principle 'Diamond Park' is expected to revive 'Taman Siswa' (a playground and a learning place) in the style of Ki Hajar Dewantara who is a pioneer of education for native Indonesians in Dutch colonial times. He has a famous proverb which was used as the motto of Indonesian Ministry of Education up to now. The proverb said "Ing ngarsa sung tulada, ing madya mangun karsa, tut wuri handayani" which translate as "for those in front should be a role model, for those in the middle should raise the spirit and create an opportunity to initiate, and for those behind should give encouragement". By actualizing a fun learning park which is able to motivate students to study hard and establish good partnership with the surrounding environment of the school. The values that are prioritized to actualize the 'Diamond Park' are religious, ethics and morals.

The application of character education should refer to the vision and mission of the School. In general, the vision of the mission of the school is to produce students who have the good achievement and noble virtuous character. The achievement of school vision and mission will bring students to educational goals of the school. Character building is the cultivation and development of character values of students which were called by Michele Borba (Kamaruddin, 2012: 226) as moral intelligent. Moral intelligent is the ability of a person to understand what is right and wrong, as he has a strong ethical belief and acts in accordance with that belief.

The implementation of school priority values and the values of PPK is done through the activities like in Table 2.

The school had and will continue to prioritize its core values and values that are prioritized in PPK. The cultivation of these values is done through the execution of habituation, extracurricular, intra-curricular (by integrating values into the material and the learning process), and through the curricular.

Based on the above matrix, it can be seen that the application of a value and another value interconnected to each other or inseparable. For example, to train students to obey to a worship and respect and love each other in religious value it contains mutual respect in nationalist value, and it contains respect for the individual dignity in integrity value.

Similarly, implanting cleanliness as part of the faith in religious value is interconnected with the responsibility as a citizen for the cleanliness of his environment. There is a wedge between the commitment in integrity and mutual cooperation value. Other activities that include all the above value are multiplying the slogans and words of motivation to encourage or motivate students to maintain cleanliness and be kind to everyone. 
Table 2. Core and Primary Values, Reason and Aims, and the Implementation

\begin{tabular}{|c|c|c|c|}
\hline No. & $\begin{array}{l}\text { Core values } \\
\text { of the School }\end{array}$ & Reasons and Aims & The Implementation \\
\hline 1. & Religious & $\begin{array}{l}\text { 1. Training students to obey in } \\
\text { worship, respect and love } \\
\text { each other. } \\
\text { 2. Embedding hygiene as part of } \\
\text { the Faith } \\
\text { 3. Training student to read the } \\
\text { Qur'an correctly according to } \\
\text { Tajwid }\end{array}$ & $\begin{array}{l}\text { - The formation of Mosque teenagers to form } \\
\text { people with a good character, faithful and } \\
\text { pious. } \\
\text { - Duta Harmoni: keeping school peace and secure } \\
\text { - Implementation of a 'Clean Day' } \\
\text { - Make a clean and healthy bathroom } \\
\text { - Activities of Tahsin and Tahfizh of Al Qur'an }\end{array}$ \\
\hline 2. & $\begin{array}{l}\text { Ethics and } \\
\text { morals }\end{array}$ & $\begin{array}{l}\text { The ethics of morality are: } \\
\text { 1. the basis for other values } \\
\text { 2. the basic value prioritized in } \\
\text { the curriculum of } 2013 \text {, } \\
\text { especially on primary } \\
\text { education. } \\
\text { 3. underlies other areas such as } \\
\text { social, cultural, economic, and } \\
\text { religious morality. }\end{array}$ & $\begin{array}{l}\text { - Saying a greeting when a teacher or guest enters } \\
\text { the class } \\
\text { - Shake hands when guests come to school } \\
\text { - Duta Harmoni: keeping the peace and security } \\
\text { of the school. He/she is an ambassador in } \\
\text { charge of welcoming guests and escort guests. }\end{array}$ \\
\hline 3. & $\begin{array}{l}\text { Local } \\
\text { Tradition and } \\
\text { Culture }\end{array}$ & $\begin{array}{l}\text { - Fostering a sense of love to } \\
\text { artistic and local culture matters } \\
\text { - Introducing cultural diversity }\end{array}$ & $\begin{array}{l}\text { - Create school's art gallery } \\
\text { - Watching Wayang Kulit performances } \\
\text { - Through social science } \\
\text { - Through composing texts report in Bahasa } \\
\text { Indonesia }\end{array}$ \\
\hline & $\begin{array}{c}\text { Primary values } \\
\text { in PPK }\end{array}$ & Reasons & Implementation \\
\hline 4. & Self-reliance & $\begin{array}{l}\text { Introducing entrepreneurship to } \\
\text { students }\end{array}$ & Inspiration class \\
\hline 5. & Nationalist & $\begin{array}{l}\text { - Fostering a sense of nationality } \\
\text { and love to the homeland } \\
\text { - Introducing Indonesian culture } \\
\text { diversity } \\
\text { - Training students skills in } \\
\text { school security }\end{array}$ & $\begin{array}{l}\text { - Flag ceremony } \\
\text { - Singing national song } \mathrm{t} \text { foster love to homeland } \\
\text { - Social science and Indonesian language } \\
\text { - School security guards }\end{array}$ \\
\hline 6. & $\begin{array}{l}\text { Gotong royong } \\
\text { (mutual } \\
\text { cooperation) }\end{array}$ & $\begin{array}{l}\text { - Work together to clean up the } \\
\text { school environment. } \\
\text { - Establish communication with } \\
\text { parents } \\
\text { - Increase responsibility and } \\
\text { solidarity }\end{array}$ & $\begin{array}{l}\text { - Cleaning Day program } \\
\text { - Establish a class forum } \\
\text { - Inviting alumni to teach }\end{array}$ \\
\hline 7. & Integrity & $\begin{array}{l}\text { - Growing integrity value (con- } \\
\text { sistency between beliefs, words, } \\
\text { and actions) in learners by in- } \\
\text { stilling values such as diligent, } \\
\text { honest, creative, and respon- } \\
\text { sible. } \\
\text { - Foster a sense of environmental } \\
\text { love } \\
\text { - Enabling the active role of } \\
\text { parents }\end{array}$ & $\begin{array}{l}\text { - Scouting activities } \\
\text { - Club of love the environment } \\
\text { - Duta Lestari: in charge of maintaining the } \\
\text { cleanliness of the school } \\
\text { - Parenting program } \\
\text { - Inspirational class } \\
\text { - Class forum } \\
\text { - workshop }\end{array}$ \\
\hline
\end{tabular}

\section{Religious Values and Other Core Values in School}

There are similar values between religious, PPK, and education for sustainable development that is harmony between environment, social, and economic condition. Yet the value of religious includes all the 
other values in PPK: independence, nationalism, mutual cooperation, and integrity, as well as the values of sustainable development embedded in religious values. Therefore one's life can not be separated from religious values he embraces. In Islamic religion and other religion, life in the world can becompared with the relationship with God, relationship with others and relationship with the environment. Two of this relationship is in accordance with sustainable development's goal. So that character education has existed since humans exist, how human beings are taught to obey their Creator, how human beings are taught to love and care each other, and how human beings are taught to utilize the natural surroundings and not to damage it.

The application of religious values besides describing the human relationship with his Creator also shows the human relationship and his relationships with the natural surroundings, so that ethical and moral values that strengthen human relationships, as well as local traditions and cultures that value human relationships with their environment, are embedded within the application of religious values. Meanwhile, the value of self-reliance is more emphasis on self-competence. The value of mutual cooperation strengthen togetherness in solving environmental problems in the life of the community, but in the life of learners in schools, mutual cooperation has the meaning of working in a team so that each team member is responsible to determine the success of team performance or the success of achieving certain goals. Nationalist values cultivate the love of the homeland and culture, while integrity proves the love, loyalty, and honesty of a citizen against his country, not just words that come out of the mouth but the consistency between words and deeds. If the word out reflects a person's love for his country but his actions harm the state, including harm to the nation and country, then there is no match between words and deeds, then it can be said that the person has no integrity.

Implementation of religious values in schools is done through the implementation of one of the five pillars of Islam that is prayer in the congregation or individually in the school mosque, and the formation of musala teenagers as well as activities of tahsin and tahfizh Alquran. This activity fosters the love of learners towards their Creator, to executes His command and to stay away from His prohibition. While tahsin and tahfizh activities make learners to become more familiar with and understand the contents of the Qur'an, know the history and love the prophets. While the other values are covered and interconnected with religious values.

\section{Self-Reliance}

Implementation of self-reliance values in schools is done through inspirational classroom activities. This activity is the introduction of various professions to learners. It is said that this is a self-reliance value planting, but introducing various professions are still far from the process of learners to be self-reliance. This activity is the introduction of tasks, functions, and benefits of various professions. The source of this activity is the parents of various professions.

Self-reliancecan be implanted through the cultivation of student's adversity quotient. In the Character Education Strengthening program, adversity quotient is a value covered in the primary value of selfreliance with the perception that with the ability to overcome adversities in the process will produce aself-reliance person. However, in the book of Concepts and Guide- 
lines, and modules of Strengthening Character Education, the books did not describe how to foster the value of the adversities quotient $(\mathrm{AQ})$ in learners. Referring to the results of previous research, the Center for Policy Research in 2016 has produced a model for growing adversity quotient referred to Stoltz theory. Adversity quotient in this model is grown through parenting from parents and teachers. Parenting between them should be synergized as not to make students confused. Where other factors outside the pattern of parenting can have an effect on students' adversity quotient.

\section{Nationalist Value}

Flag ceremonies and singing national songs are expected to foster a sense of love for the country, nation, and homeland. Implementation of this activity also indirectly provides history education of the heroes when struggled for seizing Indonesian independence. How they persistently fight and were willing to sacrifice their soul and body for the homeland and nation. This hero's struggle is called nationalist. According to a large Indonesian dictionary (Sugono, dkk. 2017), the nationalists are (1) loving the country and nation; (2) fighting for the interests of its people, not other nations. Therefore, as a leader (whether at the educational unit level, at the district/municipality, provincial or state level is an exemplary example of good practice in issuing policies that prioritize the interests of learners, the community and the nation not prioritizing learners in other schools, people in other regions or nations in other countries. The struggle of the heroes of this nation is reflected through the sentences in the songs of struggle and the activity of raising the "Sang Saka Merah Putih" flag in the spirit of maintaining independence.

\section{Integrity Value}

Integrity is the unity of faith, word, and deed so that it has a commitment, responsibility, loyalty, and honesty. The value of integrity is imparted to the learners through scouting activities and habituation, to be honest, diligent, and responsible while carrying out learning and in daily life at school. Honesty and responsibility can lead to a diligent and creative attitude to the learner, for example a learner is required to be able to perform the test or task given, then he must be studied before a test, and he is required to creatively get the ideas as an answer or solution from assigned given related to forward orientation. Creativity should arise when there is a problem to overcome, or there is a goal to be achieved. Meanwhile, according to Franken in $\mathrm{Hu}-$ man Motivation and Weisberg in Creativity (California State University, 2010) Creativity is defined as a tendency to recognize ideas, alternatives, or possibilities that might be useful in problem-solving. According to them, there are three reasons why people are motivated to be creative that requires (1) a novelty, variety, and compound stimulation; (2) communicating ideas and values; and (3) problem-solving. So to be creative one must be able to see things in a new way or from different perspectives including the uniqueness of seeing something, not by chance, quality thinking (flexible, tolerant, unexpected) or producing something not only new but also have values and in accordance with the cognitive demands of certain conditions.

Creativity in students of this research seen from their achievement in drawing/ painting activities. With this activity, learners can pour and develop their imagination, feelings, and ideas into meaningful images. From previous experiences, this school has the most achievements in the drawing 
contest. If there is a drawing competition in Mataram city, then the $1-6$ winner is achieved by the students from this school.

\section{Gotong-Royong or Mutual Cooperation}

The gotong-royong value is implemented by clean day and gardening activities. Clean day activities including cleaning up the school ground, classrooms, praying rooms, bathrooms, and libraries. Students are grouped into several groups, some group had to sweep and mop rooms and others collect and dispose garbage from the schoolyard. While gardening activities did per class. Each class has planted plants and they are responsible for caring those plants. Plants in the garden are chili, pare, kale, greens mustard, and flowers.

\section{Supporting Factors in Implementing Cha- racters Value}

There is a plus point in this school that makes the implantation of character values well implemented, that is principal leadership. The principal is committed and seeks to actualize the Vision of the school to be real. Day and Sammons (Rev, 2014:27) stated that an effective principal provides clear vision and direction. They have priorities and direct their staff to focus on the things that matter, and not let them turn to initiatives that have little effect on student progress.

The principal also has knowledge of what is going on in the classroom, the principal knows the weaknesses and strengths of his staff. One teacher classifies students on the basis of the speed at which they receive and understand the lesson in order to make the teacher easier to provide material and enrichment. While the headmaster says grouping by mixing some students with different speed in accepting and understanding in learning also provides a lot of benefits. Peer learning takes place in this style of grouping. Students who are clever will help students who are less clever. In this grouping also occurs values of empathy, to receive and help other students in need.

There is a sharing of knowledge and an outpouring of affection between people. Thus it appears that principals appreciate the efforts (classroom management) undertaken by teachers and understand the benefits of such efforts. In addition, the role and commitment of teachers are very helpful in the implementation of these activities in schools. Likewise, the support and participation of children, committees, school alumni, and the business institution in the implementation of these activities encourage the continuity of this program at schools. School alumni give a meaningful contribution to the implementation of some activities in school. In the future, they will contribute as resource persons to specific activities according to their profession. One of the teachers said.

Extracurricular activities should be more varied while school operational fund (BOS) from the central government only for the teacher who came from this school and teach in this school, bringing in teachers from other school has a higher cost. Therefore school activities was adjusted with the availability of this fund.

Other teacher said, "In the future, this school had not use much money as the school selected alumni to be embraced, for example, alumni who worked as a policeman will train police boys in school to introduce and acknowledged students with police work and function." 


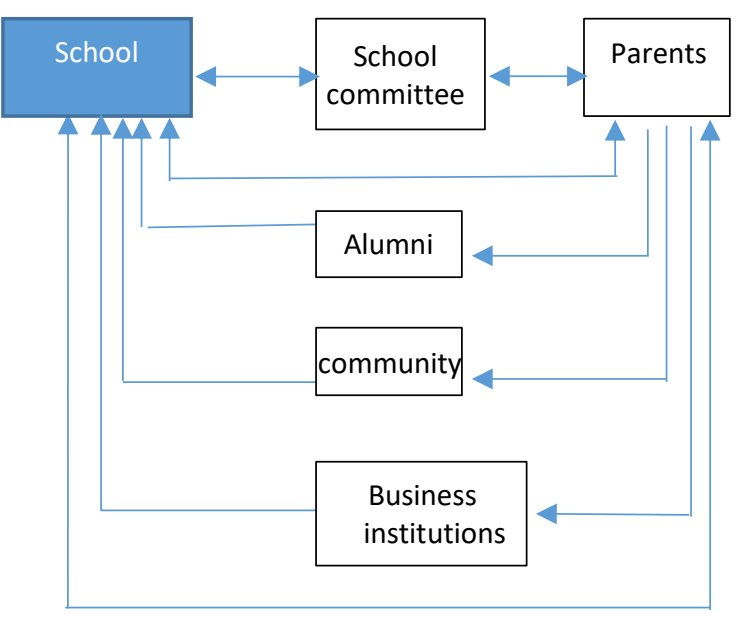

Figure 1. The Coordination and Supporting Network to School Activities Obstacles in Implementing Character Education through Strengthening Character Education (PPK) Program and School Effort to Solve Them

A business institution that supports school activities is also a company where a parent of students work so that the cooperation between business institution and school bridged by parents or alumni. At the Figure 1 below we can see that there is a network of schools with families, communities in the neighborhood, alumni of the school, and business institutions.

School found some difficulties in implementing PPK program and tried to overcome them as described below.

- In socialization, there was some committee member that did not attend the activity that the school should reschedule the socialization activities, and this was already done.

- The school has to form a Team of Developers of curriculum that characterized by PPK to compose and plan learning that was characterized by PPK as there should an adjustment between the concept of Curriculum 2013 and concept of PPK. School invites interviewees of Curriculum 2013 and PPK.
- In establishing school art studio, the school found that schedule and programs of art studio had not neatly arranged. The locations that were needed to carry out the activities cannot be determined because the school was in repair. In solving this problem, school adjusted the schedule with the availability of rooms and school condition.

- Class forum as a forum of parents met obstacles as the board and its members were busy. The meeting that should be done once a month and coordination with the school which should be conducted every three months did not go well. The school was proactive to establish a communication with the board of the forum and establish online communication networks through social media such as WhatsApp.

\section{CONCLUSION}

Socialization of the implementation of PPK programs has been implemented throughout the school, not only in the environment within the school but also in the environment outside the school which includes socialization to all teachers and school residents, parents, and principals and teachers in the same cluster area and society.

Schools have implemented the five core values of PPK and enriched with Core Value applied in schools namely Ethics and Morality, as well as Local Traditions and Cultures. Within these key values, there are several sub-values that have been embedded and implemented in schools such as fostering a sense of nationalism and love of the country, recognizing the diversity of Indonesian culture and training in school security skills in the main values of Nationalist; cooperation, communication, improvement of responsibility and solidarity 
in the main value of Gotong-royong; consistent, honest, creative and responsible in the main value of integrity. However, there are also sub-value that have not been applied such as Adversity Quotient as a sub-value of self-reliance. Adversity quotient is the basis of student self-reliance. Some of the sub-values of the main value include in some of the other main values, therefore character values cannot stand alone so that planting and application can be done based on priority values through certain activities or themes. This does not rule out the possibility to bring up other values in an activity or theme of learning. Conversely, based on the theme of a particular learning or activity, a matrix of values can be created in the lesson to facilitate the assessment of students' character.

School had tried to overcome the problem associated with the implementation of character education such as socialization of the program, the usage of art studio room, and forum between school and parents by rearranging schedule, communication, and coordination between schools and parents through social media, implementation of the program by adjusting the the concept of curriculum and the concept of PPK. In these efforts communication, coordination and cooperation were needed. It means that PPK should consider to familiarize and cultivate the 3C (Communication, Coordination, and Cooperation) in school life, besides the $4 \mathrm{C}$ (Critical thinking, Communication skills, Creativity and Innovation, and Collaboration). Whereas Life skills are needed to be learned and practiced by students in order to live their lives independently.

\section{ACKNOWLEDGMENT}

The author is grateful to Allah for the completion of this article and can be pu- blished in this edition of the Jurnal Pendidikan Karakter. The author would like to sincerely thank to the chairman of the editorial board of Jurnal Pendidikan Karakter for the acceptance and publication of this article

\section{REFERENCES}

Agboola, A dan Tsai, K.C. (2012). Bring character education into classroom. European Journal of Educational Research, 1(2), 163-170. Retrieved from: http:/ / files.eric.ed.gov/ full text/EJ1086349.

Battistich, V. (2011). Character education, prevention, and positive youth development University of Missouri, St. Louis. Retrieved from: http:/ / www.character.org/wp-content/uploads/2011/12/White_Paper_Battistich.pdf.

California State University. (2010). What is creativity? Retrieved from: https://www.csun.edu/ vcpsy00h/ creativity/define.htm.

Day, C. and Sammons, P. (2014). Successful school leadership. The University of Nottingham: Education Development Trust, p. 13. Retrieved from: https://www.education developmenttrust.com/ /media/EDT/Reports/Resear ch/2015/r-successful-school-leadership.pdf.

Dodge, P.R. (2011). Managing school behavior: A qualitative case study. Graduate Theses and Dissertations of Iowa State University. Retrieved from: http://lib.dr.iastate.edu/cgi/viewcontent. cgi $?$ article $=3016 \&$ context $=$ etd .

Efrini, M. (2016). Discovery learning method based on scientific approach in curriculum 2013 in teaching english at senior high school. Paper. Presented at the International Seminar on Education. Faculty of Tarbiyah and Teacher Training English Language Education Program, Graduate Program The State University of Padang, 93-102. 
Jolls, T. (2008). The Impact of technology on character education. prepared for U.S. Departement of Education. Character Education Symposium 2008. Retrieved from: http://www.medialit.org/sites/default/files/DOE\%20Jolls\%20Impact $\% 20$ of $\% 20$ Tech $\% 20$ on \%20Char\%20Education.pdf.

Kamaruddin, S.A. (2012). Character education and students social behavior. Journal of Education and Learning, 6(4), 223-230. Retrieved from: file:///C:/Users/user/Downloads/166-1871-PB.pdf.

Kementerian Pendidikan dan Kebudayaan (2016). Konsep dan pedoman penguatan pendidikan karakter: Tingkat Sekolah Dasar dan Sekolah Menengah Pertama (Book of concepts and guidelines for strengthening character education at the Elementary and Junior High School Level). Jakarta: Kemendikbud.

Khafid, S. (2017). Gubernur Zainul Majdi dukung penguatan pendidikan karakter. Retrieved from: https://nasional.tempo.co/read/890318/gubernur-zainul-majdi-dukung-penguatan-pendidikan-karakter\#1BhCR0bDzG7Oq$1 G 3.99$.

KPAI. (2016). Kasus pengaduan anak berdasarkan klaster perlindungan anak. Data KPAI Update per 24 Oktober 2016. Retrieved from: www.ucarecdn.com/2998b407-30a9-4949-ad65-7e6647bee610/.
Marzuki. (2009). Pembinaan akhlak mulia dalam berhubungan antar sesama manusia dalam perspektif Islam. Humanika: Kajian Ilmiah Mata Kuliah Umum, 9(10, 25-38. Retrieved from: https://journal.uny.ac.id/index.php/humani $\mathrm{ka} /$ article/view/3781/3257.

Maskur, F. (2016). Catatan akhir tahun KPAI: Anak sebagai pelaku kejahatan meningkat. Retrieved from: http://lifestyle.bisnis.com/read/20160102/236/5064 40/catatan-akhir-tahun-kpai-anak-sebagai-pelaku-kejahatan-meningkat.

Narvaez, D. \& Lapsley, D.K. (2008). Teaching moral character: Two alternatives for teacher education. The Teacher Educator, 43(1), 156-172. DOI: https://doi.org/10.1080/08878730701838983.

Sylviyanah,S.(2012). Pembinaan akhlak mulia pada Sekolah Dasar (Studi deskriptif pada Sekolah Dasar Islam Terpadu Nur Rahman). Jurnal Tarbawi, 1(3), 191-203. Retrieved from: http://jurnal.upi.edu/file/04_Pembinaan_Akh lak_Mulia_Pada_Sekolah_Dasar__Selly.pdf.

Tim Penyusun Kamus. (2008). Kamus besar bahasa Indonesia. Jakarta: Departemen Pendidikan Nasional.

Wilson, V. (2014). Research methods: Triangulation. Evidence Based Library and Information Practice, 9(1), 74-75. DOI:https://doi.org/10.18438/B8WW3X. 